\title{
Concrete Cleaning, Inc. Centrifugal Shot Blaster: Baseline Report; Summary
}

\section{Topical Report July 31, 1997}

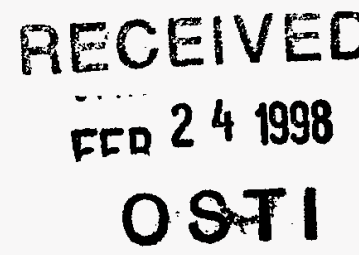

Work Performed Under Contract No.: DE-FC21-95MC32260

For

U.S. Department of Energy

Office of Environmental Management

Office of Technology Development

1000 Independence Avenue

Washington, DC 20585
U.S. Department of Energy

Office of Fossil Energy

Federal Energy Technology Center

Morgantown Site

P.O. Box 880

Morgantown, West Virginia 26507-0880

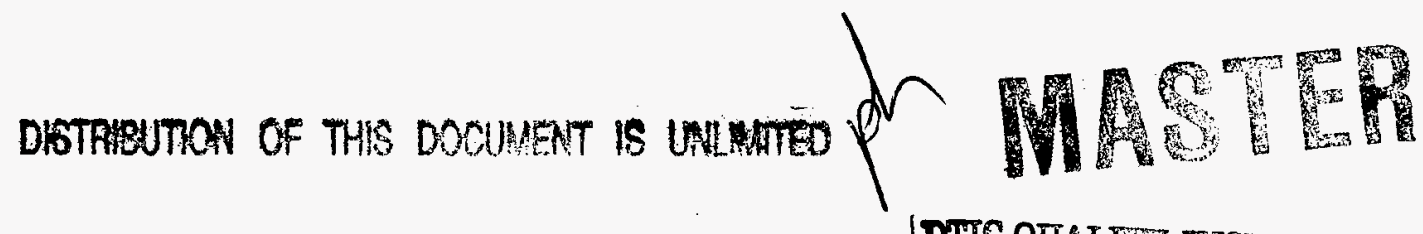

By

(DIC QUELTHT THEYZUTED J

Operating Engineers National Hazmat Program

250 Airport Circle

Beaver, West Virginia 25813 


\section{Disclaimer}

This report was prepared as an account of work sponsored by an agency of the United States Government. Neither the United States Government nor any agency thereof, nor any of their employees, makes any warranty, express or implied, or assumes any legal liability or responsibility for the accuracy, completeness, or usefulness of any information, apparatus, product, or process disclosed, or represents that its use would not infringe privately owned rights. Reference herein to any specific commercial product, process, or service by trade name, trademark, manufacturer, or otherwise does not necessarily constitute or imply its endorsement, recommendation, or favoring by the United States Government or any agency thereof. The views and opinions of authors expressed herein do not necessarily state or reflect those of the United States Government or any agency thereof. 


\section{CONCRETE CLEANING, INC. - CENTRIFUGAL SHOT BLASTER HUMAN FACTORS ASSESSMENT - BASELINE}

\section{SECTION 1 - SUMMARY}

\section{Technology Description}

The centrifugal shot blaster is an electronically operated shot-blast machine that removes layers of concrete of varying depths. Hardened steel shot propelled at a high rate of speed abrades the surface of the concrete. The depth of material removed is determined by the rate of speed the machine is traveling and the volume of shot being fired into the blast chamber. The steel shot is reused until it is pulverized to dust, which is deposited in the waste container with the concrete being removed. Debris is continually vacuumed by a large dust collection system attached to the shot blaster.

\section{Key Results}

The safety and health evaluation during the testing demonstration focused on two main areas of exposure: dust and noise. Dust exposure was minimal, but noise exposure was potentially significant. Further testing for each of these exposures is recommended, because the outdoor environment where the testing demonstration took place may cause the results to be inapplicable to enclosed work areas. It is feasible that the dust and noise levels will be higher in an enclosed operating environment. Other safety and health issues found were ergonomics, heat stress, tripping hazards, electrical hazards, and lockout/tagout.

\section{SECTION 2 - HEALTH AND SAFETY EVALUATION}

\section{General Safety and Health Concerns}

Safety and health issues of concern with the concrete cleaning shot blast technology included tripping hazards, electrical hazards, rotating machinery, lockout/tagout, heat stress, ergonomics, noise, dust, and communication.

\section{Industrial Hygiene Monitoring}

During the testing demonstration, sampling was conducted for dust and noise. The wet-bulb globe temperature was monitored.

Observational evaluation was conducted for ergonomics and arm-hand vibration and wholebody vibration.

Ergonomically there is potential for muscle/back stress and/or injury to the knees. Of particular concern was the need to manually shovel the dust from the dust pan. This increases back stress and causes an increase in exposure to the contaminant.

Heat stress was monitored using wet-bulb globe measurements and worker physiological measurements such as blood pressure, puise, and temperature and work/rest regimen recommendations were made in accordance with ACGIH recommendations.

Personal air sampling was conducted on the equipment operator and the assistant. Personal dust sampling results were below allowable levels. Noise monitoring resulted in a dose of $17.36 \%$ or an 8-hour TWA of $77.4 \mathrm{dBA}$ and a dose of $47.37 \%$ or an 8-hour TWA of $84.6 \mathrm{dBA}$ for the operator, and $6.30 \%$ or an 8-hour TWA of $70.1 \mathrm{dBA}$ for the assistant. This does not exceed the OSHA action level of $85 \mathrm{dBA}$ and the permissible exposure of $90 \mathrm{dBA}$ for the amount of time sampled. An overexposure may occur for a full 8-hour work shift. A hearing conservation program may be necessary for anyone working with or around this equipment.

\section{Human Factors Interface}

The technology was evaluated for operator interface with Anti-C PPE including a full face airpurifying respirator. Operators wearing the PPE experienced some visibility problems due to the full face respirator, and some loss of tactile sensation and dexterity during maintenance activities. In addition, there was an increase in 
heat stress associated with the protective ensemble.

\section{SECTION 3 - TECHNOLOGY APPLICABILITY}

On observation, the technology did not deposit much visible dust into the atmosphere. Air monitoring did not evidence an excessive dust level. There was some larger debris left on the surface at the sides of the scabbling head.

The shot blaster will need to be torn down to be decontaminated. This will not necessarily guarantee that decontamination for alpha radiation will be complete. It will be difficult to survey for alpha contamination due to all of the small spaces in the equipment that are hard to reach with a probe. According to the technology representative, many parts, such as the hoses and brushes, may be considered consumables.

\section{SECTION 4 - REGULATORY/POLICY ISSUES}

The site safety and health personnel where the centrifugal shot blaster technology is being used need to be concerned with safety and health regulations applicable to the issues discussed above. Regulations that will apply may include but not be limited to the following areas: housekeeping, electrical, machine guarding, lockout/tagout, ionizing radiation, toxic and hazardous substances, noise, respiratory protection, PPE, HAZCOM, and HAZWOPER.

\section{SECTION 5 - OPERATIONAL CONSIDERATIONS \& RECOMMENDATIONS}

Recommendations for improved worker safety and health include good housekeeping, ergonomic training and awareness, a system to increase operator visibility in the front of the equipment, a dead man switch, relocation of the E-stop, assuring proper vacuum adjustment for adequate air flow, using a HEPA vacuum system, and engineering, administrative, and/or hearing protection be used for compliance with the OSHA noise standard.

Due to the windy outdoor testing conditions, it is recommended that the noise and dust monitoring be conducted while the technology is in use in an enclosed environment. Since Level A or Level B PPE may be required for contaminants other than alpha radiation, it is recommended that a human factors interface for these levels of protection be conducted.

Research supported by the U.S. 'Department of Energy's Federal Energy Technology Center, under cooperative agreement DE-FC21-95MC32260 with the Operating Engineers National HAZMAT Program, 250 Airport Circle, Beaver, WV 25813, phone 304-253-8674, fax 304-253-7758. This report was prepared with the support of the US DOE; however, any opinions, findings, conclusions, or recommendations expressed herein are those of the author(s) and do not necessarily reflect the views of the DOE. 
Report Number (14)DoE/me/32260--5836

subl. Date (11) $\frac{19970731}{\Delta 0 \varepsilon / \varepsilon m ; \Delta 0 \varepsilon / F E, X F}$
sponsor Code (18)
JC Category (19) UC-2000; UC-101, DOE/ER 